\title{
The Usage of Telecommunication Technologies in the Integration of Universities and Business
}

\author{
http://dx.doi.org/10.3991/ijac.v7i2.3725 \\ R.L. Sakhapov ${ }^{1}$, S.G. Absalyamova ${ }^{2}$ \\ ${ }^{1}$ Kazan State University of Architecture and Engineering, Kazan, Russia \\ ${ }^{2}$ Kazan (Volga region) Federal University, Kazan, Russia
}

\begin{abstract}
Nowadays the world economy suffers a global innovation gap, which reveals itself in essential disproportions in innovative development of particular countries. The deep inequality is also observed in the sphere of innovations between various geographical regions. Unfortunately, Russia does not belong to the countries - leaders of the innovative development. The reasons of its underrun should be searched for in the sphere of organization of innovative process on the national level, in the state and condition of the national innovative system, and in the low effectiveness of the cooperation between universities and business. An active introduction of telecommunicational technologies can play a positive role in integration of education and business.
\end{abstract}

Index Terms - global innovation gap, integration of universities and business, international cooperation, telecommunicational technologies.

\section{INTRODUCTION}

According to the analytical report "Global Innovation Index 2013", Russia takes the 62nd place by its global innovative index [1]. Russia belongs to the group of countries where expenses on innovations exceed the average level of the observed countries, while results of the innovative activity fall considerably behind the average numbers.

Conducted investigations have shown that the state of the innovative sphere, expenses of GDP on scientific research and development are in close correlation with the index of Russian research institutes quality. Thus, in 2010 this index equaled 49.93 in Russia, while in the USA it made up 82.53 and in Germany 81.13.

This indicates the presence of a global innovation gap between the countries [2].

Russian scientific thought cannot create effective model of increasing innovative activity of domestic enterprises and branches. Significant gap remains in a number of indicators, characterizing introduction of innovative technologies and development of integration processes between science, education and production. Index of cooperation of universities (science and education) with industry is almost two times lower in Russia than that in the USA and Germany, and 1.4 times lower than that in China.

GDP in Russia today is $31-32 \%$ from the level of the USA, which is 2.5 times lower than the corresponding figures in England, France and Germany. According to the rating agencies prognoses, if Russian economy grows nearly for $4 \%$ a year, it will help it to take the 15 th place by 2050 , but the gap between the leading countries and Russia will only increase during these years [3].
The national innovative system of Russia today is misbalanced. Its core elements, such as science and educational institutions, industrial enterprises, innovative infrastructure exist independently from each other; there is no cooperation mechanism between them.

Two-sided integration prevails in Russia: integration among educational and scientific institutions is on a high level in the scientific and educational spheres. Business representatives prefer science in research sphere and higher education institutions in educational sphere. Meanwhile, Russia should develop tree-sided correlation of science, education and business by making three-sided contracts, creating collaborative research and development centers, laboratories, developing of cooperation as part of scientific educational complex with the detachment of the guiding link, which determines priority partners and branches of activities. Only such three-sided cooperation of these institutions can create multiplication effect and turn Russian economy to the innovative way of development.

Developing countries solve the problem of overcoming technological backwardness by means of concentration of resources on breakthrough directions of the new technological mode, multiple increasing in innovative and investment activity, which provide new quality of economic growth.

The project of development and renovation of Russia's transport infrastructure can become a powerful locomotive of innovations development and one of the «centers of crystallization» of innovative activity. Progressive foreign countries experience of creating technological platforms based on combination of three factors: apparent demand, intellectual capital and new foreign technologies can be effectively introduced particularly in the sphere of road construction.

\section{DEVELOPMENT OF INTERNATIONAL COOPERATION}

The department of road building machines of Kazan State University of Architecture and Engineering actively enlarges partnership both with national and foreign companies, having established on its platform international educational center of transfer of modern technologies in the field of road construction together with German company Wirtgen, Swedish company Volvo OOO "Ferronordic Machines", Chinese companies Guilin Huali Heavy Industries Co. Ltd, Xugong Construction Machinery Group [4].

International educational center regularly holds international seminars and meetings with leading foreign specialists for the managers of enterprises of road construction 
industry of Republic of Tatarstan. During summer practice three best students of road construction department visit Wirtgen Group plants such as: Kleeman, Hamm, Vogele and Wirtgen. They study structures of modern road building machines, and in practice learn the newest technologies of roads laying in Germany, get acquainted with the newest methods and ways of their production.

Road building machines department has also signed an agreement with Chinese Geologic University (Wuhan) and Xugong Construction Machinery Group plant about creating a course "Application of Trenchless Technologies in Construction", aiming at studying and practical using of progressive experience. For example, Xugong Construction Machinery Group has formed a classroom on the platform of road building machines department and equipped it with necessary joints and instruments for demonstration aid; and Chinese Geologic University (Wuhan) sends its specialists in the field of trenchless technologies and horizontal directional drilling for holding training and educational seminars and conferences to exchange experience.

Realization of the mentioned above projects supplies the department with various groups of resources: material resources, i.e. access to unique equipment, financial resources, i.e. financial support of innovative projects, and immaterial resources, i.e. intellectual property, which is conveyed in accordance with licensing agreements and by using human resources and knowledge.

International educational center supports practice of collaborative participating of higher-education teaching staff in contests for gaining orders for investigations and project engineering, and in international programs and projects. All these allow forming the environment favorable for integrative processes in scientific-educational community. Challenges from developing technological market have encouraged active formation of patent portfolio of the department.

Realization of innovative projects is accompanied with creation of small innovative enterprises. Road building machines department is working hard on creation of Technical Park "The Roller", which will help to increase innovative activity in the road construction industry, and create new transfer channels of progressive technologies.

\section{USAGE OF TELECOMMUNICATIONAL}

\section{TECHNOLOGIES IN INTEGRATIONAL PROCESSES}

Telecommunicational technologies and interactive methods of education are widely used by the department for gaining effectiveness of integrational processes and increasing the quality of education.

Formation of student's portfolio, usage of casetechnologies, creation of focus-groups, realization of business and role plays, case-study and on-line testing play a significant role among interactive methods. After practicing abroad, students defend their reports in on-line mode, creating participation effect of the host party.

The department actively develops education by means of network resources, which broadens interaction between students and teaching staff, provides dialogue exchange between the participants of the educational process in online and off-line modes. Synchronous holding of interactive courses with instructing in on-line mode, as well as with the further asynchronous discussion, is actively practiced in the process of teaching.

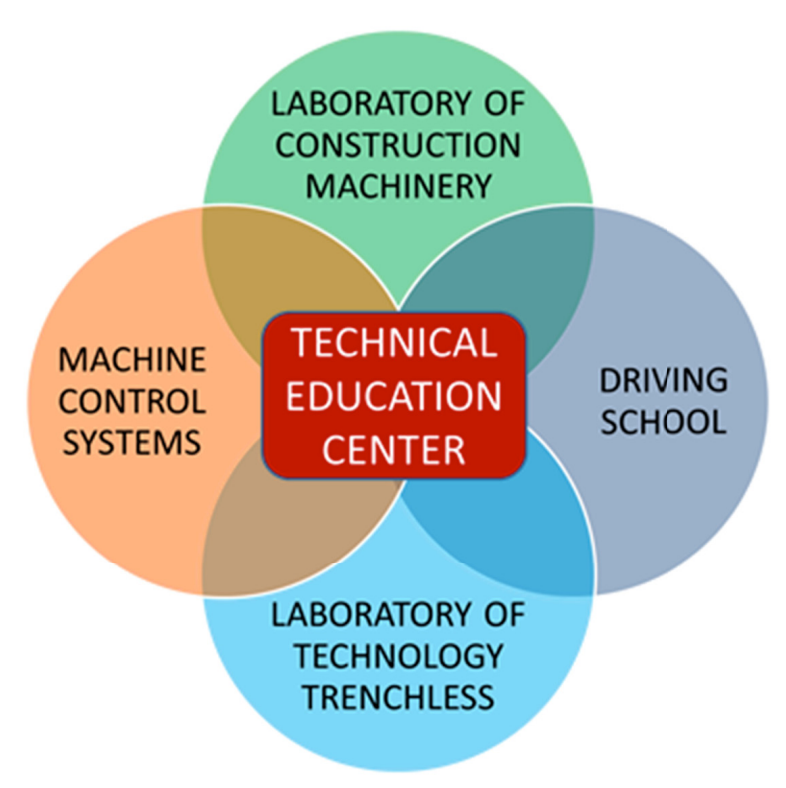

Figure 1. The Scheme of the Center.

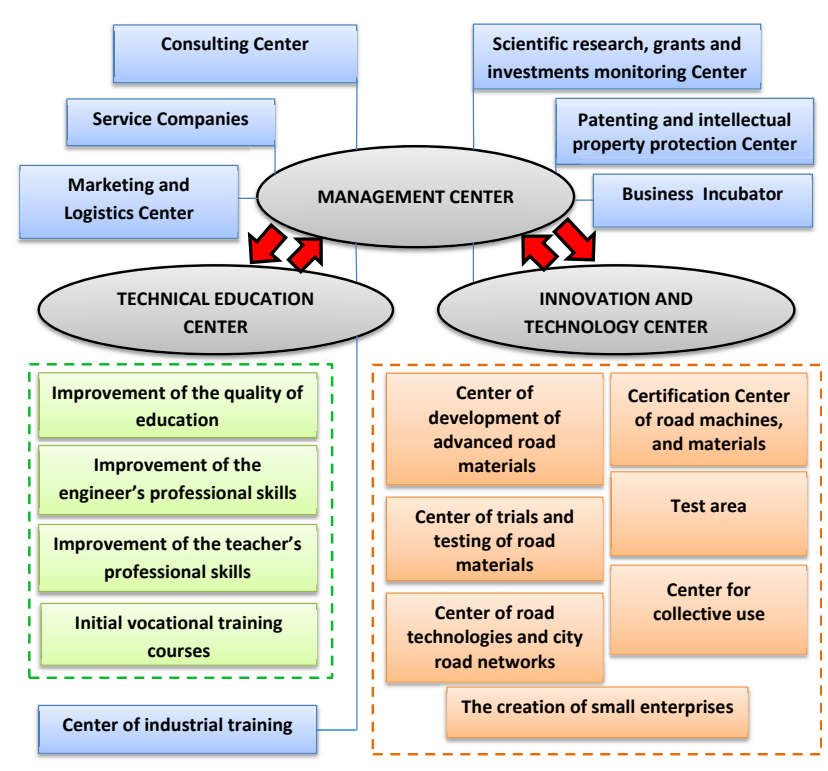

Figure 2. The Scheme of the Road Technology Park «Roller».

Wirtgen Company representatives hold lectures about modern world tendencies in the development of road construction industry for students and specialists, who upgrade their skills in the International educational center. During educational seminars video conferences, round tables, on-line debates and discussions, forums for business as well as for informal communication are held both with Russian representatives of road construction industry and foreign partners.

Qualification upgrading courses are constantly held on the platform of the department, where exploitation peculiarities of foreign road construction machines of such companies as Wirtgen, Vogele, Hamm, and Volvo are studied, and machines of modern trenchless technologies of horizontal directional drilling are observed. Information technologies are actively used in this process.

Cooperation of the universities with business structures on the bases of telecommunicational technologies opens: 
1. ability of participating in solving real production tasks in on-line mode;

2. adjusting of one's activities to international standards in the educational sphere;

3. ability to get feedback from the consumers of scientific-educational services;

4. acceleration of the transfer of knowledge and practical experience;

5. training of higher level specialists by access to new educational and information resources;

6. access to new markets of educational services in the form of distance education;

7. continual renewal of acquired knowledge and upgrading of professional qualification by means of studying multimedia courses.

The introduction of information technology into the process of continuing engineering education has led to the formation of a new individual-oriented paradigm. It is based on virtualization of the educational process. Today the department is working to create electronic textbooks, electronic reference books and glossaries, coaching and monitoring software. This assumes widespread use of multimedia technology, local and global communications network. Unlike the traditional forms of education, the student can individually select the rhythm of studying, speed of course, group mates, educational and reference materials. Virtual project-based teams to solve specific production problems are being created. All of this allows increasing the level of the professional skills of trained engineers.

According to the results of the international research in the sphere of innovations "Global Innovative Barometer 2012 ", only $35 \%$ of the examined agreed that Russian schools and universities provide level of education, necessary for formation of innovative leaders of the future (on average $59 \%$ of 22 countries; $52 \%$ of BRIC countries). Among the most important factors that could contribute to gaining success in innovative activities, $64 \%$ of Russian managers emphasized the availability of the employees, who can think creatively and find out-of-the-box solutions, and $42 \%$ of the respondents wanted to see employees with a higher level of technical competence [5]. The represented data enable to evaluate really the level of qualification of Russian specialists and search for cardinal new ways of its increase, among other things by means of strengthening the integration between universities and business on the bases of telecommunication technologies.

\section{CONCLUSION}

Transition of Russian economy to the innovation-based development is impossible without strengthening the inte-

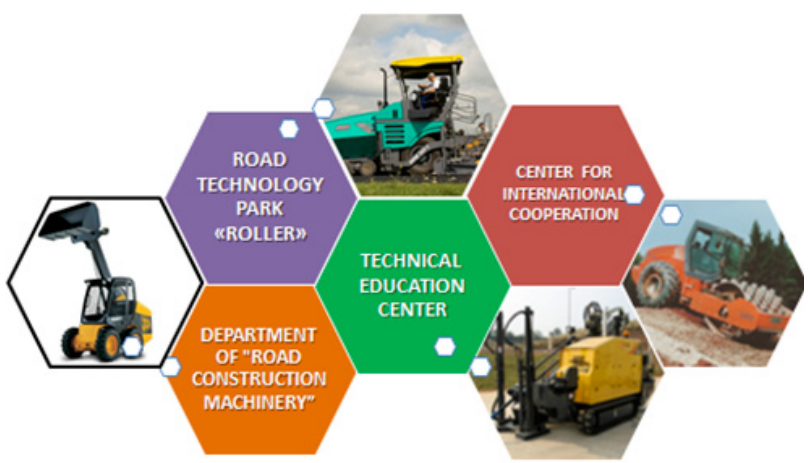

Figure 3. The Scheme of the Department Development.

gration between universities and business. This will favor narrowing the technological gap and returning Russia into elite technological club. Development of global partnership between educational institutions and leading global producers and Russian companies will increase specialists' training quality, and activate conducting Russian scientific research. Broadening of integration processes today is impossible without active application of telecommunicational technologies. The usage of them opens new possibilities in educational and scientific spheres.

\section{REFERENCES}

[1] «The Global Innovation Index 2013»

[2] http:// www.globalinnovationindex.org., 2013.

[3] Castellacci F. Closing the Technology Gap? // Review of Development Economics. Vol. 15. Issue pp. 180-197, 2011.

[4] HSBC «The World in 2050»//Global Economics, January, - 46 p., 2011.

[5] Sakhapov R., Absalyamova S. Integration of Universities and Business As the Condition of Formation of the Innovative Economy // 16th International Conference on Interactive Collaborative Learning \& 42nd IGIP International Conference on Engineering Pedagogy, Kazan, Russia, pp. 192-194, 2013.

[6] «Global Innovation Barometer 2012». http://gtmarket.ru/news/2012/03/06/4088.

\section{AUTHORS}

Sakhapov R.L., doctor of technical sciences, professor, is Head of Department "Road Construction Machinery" at Kazan State University of Architecture and Engineering, Kazan, Russia (rustem@sakhapov.ru).

Absalyamova S.G., candidate of economic sciences, is Associate Professor of "Economic Theory" at Kazan (Volga region) Federal University, Kazan, Russia, (s.absalyamova@yandex.ru).

Submitted 30 March 2014. Published as re-submitted by the authors 08 June 2014. 